TOMASZ KOMORNICKI

Polska Akademia Nauk

Warszawa

\title{
Rola wymiany towarowej ze wschodnimi sąsiadami Polski w gospodarce lokalnej
}

\section{WSTĘP}

Artykuł poświęcony jest znaczeniu jakie dla gospodarki lokalnej Polski Wschodniej ma obecnie wymiana towarowa z Rosją, Ukrainą i Białorusią. Prezentuje on, w znacznej części, wyniki studiów realizowanych w ramach projektu badawczego Ministerstwa Nauki i Szkolnictwa Wyższego dotyczącego przepływów przez polski odcinek zewnętrznej granicy Unii Europejskiej (projekt Nr NN306251133; Komornicki 2010). W opracowaniu wykorzystano także wyniki ekspertyzy wykonywanej przez Autora dla Ministerstwa Rozwoju Regionalnego (Komornicki 2009). Rola obrotów handlowych na kierunku wschodnim rozpatrywana jest w kontekście stwarzanych przez nie szans i zagrożeń dla szeroko rozumianych terenów przygranicznych.

Założono, że znaczenie wymiany z krajami sąsiednimi dla gospodarki lokalnej może się wyrażać poprzez:

- eksport produktów wytworzonych w danej jednostce przestrzennej na rynki państw sąsiednich;

- obsługę ruchu tranzytowego, w tym zwłaszcza ruchu towarowego generowanego przez polski handel zagraniczny;

- drobny nierejestrowany handel przygraniczny.

Wszystkie wymienione elementy mogą potencjalnie wpływać korzystnie na gospodarkę lokalną (w tym zwłaszcza na lokalny rynek pracy). Jednocześnie mogą one także stwarzać dla tej gospodarki pewne zagrożenia. Nadmierne skoncentrowanie eksporterów na rynku krajów sąsiednich zwiększa ryzyko „importu” sytuacji kryzysowych (Gorzelak 2009, ciężki tranzyt towarowy generuje znaczne koszty zewnętrzne (oddziaływanie na środowisko, bezpieczeństwo ruchu drogowego; Komornicki 2007), a handel przygraniczny (zwłaszcza towarami objętymi akcyzą) stanowi nieuczciwą konkurencję dla lokalnych przedsiębiorców, a poprzez kryminalizację podejmowanych aktywności sprzyja wykluczeniu niektórych przygranicznych grup społecznych.

Przedmiotem badań były przede wszystkim cztery wschodnie województwa przygraniczne. Niektóre zagadnienia (zwłaszcza dotyczące handlu zagranicznego) prezentowano 
w ujęciu ogólnokrajowym. Analizowano trzy aspekty zagadnienia: (a) wielkość eksportu rejestrowanego na poziomie powiatów względem produkcji sprzedanej przemysłu oraz udział partnerów wschodnich w tym eksporcie; (b) kierunki ruchu samochodów ciężarowych oraz przepływu towarów w polskim handlu zagranicznym na poziomie korytarzy transportowych i przejść granicznych; (c) strukturę ruchu osobowego na wybranych przejściach granicznych, pomocną w oszacowaniu skali nierejstrowanych powiązań gospodarczych. W pierwszych dwóch przypadkach oparto się na danych Departamentu Celnego Ministerstwa Finansów, w drugim i trzecim na materiałach Straży Granicznej.

\section{EKSPORT OFICJALNY}

Rozkłady wymiany handlowej z trzema wschodnimi krajami sąsiednimi są zróżnicowane przestrzennie oraz zmienne w czasie. W skali kraju wschodni partnerzy największą rolę odgrywają w eksporcie z województwa podlaskiego (blisko 23\%), podkarpackiego i mazowieckiego. Łączny udział tych państw w eksporcie wzrastał z poziomu $6 \% \mathrm{w}$ roku 2000 do 8,3\% w 2005 i blisko 9\% w 2007. Największy wzrost udziału w latach 2000-2007 zaobserwowano w województwach lubuskim, świętokrzyskim i podlaskim. Jest znamienne, że szybki spadek udziału wystąpił w przygranicznym województwie lubelskim. Jeszcze w roku 2000 województwo to generowało 9\% eksportu do Rosji, Ukrainy i Białorusi; w 2007 już tylko niecałe 3\%. Jednocześnie wzrosła koncentracja wywozu na kierunku wschodnim w mazowieckim (do 33\% w 2007 r.), śląskim, wielkopolskim i dolnośląskim. Tym samym można przyjąć, że wprawdzie partnerzy wschodni nadal relatywnie większą rolę w lokalnej gospodarce odgrywają w województwach wschodnich, to jednak największe potoki wywozu na tym kierunku odsunęły się od bezpośredniej granicy w stronę głównych zagłębi eksportowych Polski centralnej i zachodniej (Komornicki 2009).

Wymiana handlowa z Ukrainą już w latach 90. odznaczała się koncentracją w obszarze przygranicznym oraz wzdłuż dwóch osi transportowo-rozwojowych: równoleżnikowej od granicy z sąsiadem w kierunku Krakowa i skośnej od granicy przez Lublin w stronę Warszawy. W latach 2000-2007 doszło do wydłużenia obu wymienionych stref silniejszych związków ekonomicznych (ryc. 1). Obszar skupiający jednostki o ponad 5\% udziale Ukrainy w wywozie zwiększył się w kierunku zachodnim i północnym. Jednocześnie zmalało znaczenie wymiany $\mathrm{z}$ bezpośrednim sąsiadem na terenach przygranicznych województw podkarpackiego i lubelskiego. Mimo to nadal tam właśnie znajdują się jednostki, z których ponad 80\% wywozu trafia na Ukrainę (powiaty przemyski, jarosławski i miasto Zamość). Spośród największych miast (w skali kraju) zdecydowanie najsilniejsze związki z partnerem ukraińskim ma Lublin (17,5\% eksportu).

W latach 2000-2007 udział Białorusi w wywozie z Polski pozostawał ustabilizowany (około 0,8), pomimo ograniczeń politycznych. Rozkład przestrzenny jednostek powiązanych z rynkiem białoruskim nawiązywał i nawiązuje do odległości geograficznej do granicy z tym krajem. Zmiany tego rozkładu w analizowanych latach nie były spektakularne (ryc. 2). Wystapił wprawdzie wzrost eksportu z jednostek w głębi kraju (analogiczny do opisanego w przypadku handlu z Ukraina), dotyczyło to jednak ograniczonej grupy powiatów. Najsilniej powiązane z Białorusią pozostały jednostki z województwa podlaskiego (powiat sokólski, 43\% wywozu) i północnej części lubelskiego, a z dużych ośrodków Białystok (8,5\% wywozu w 2007 roku) 

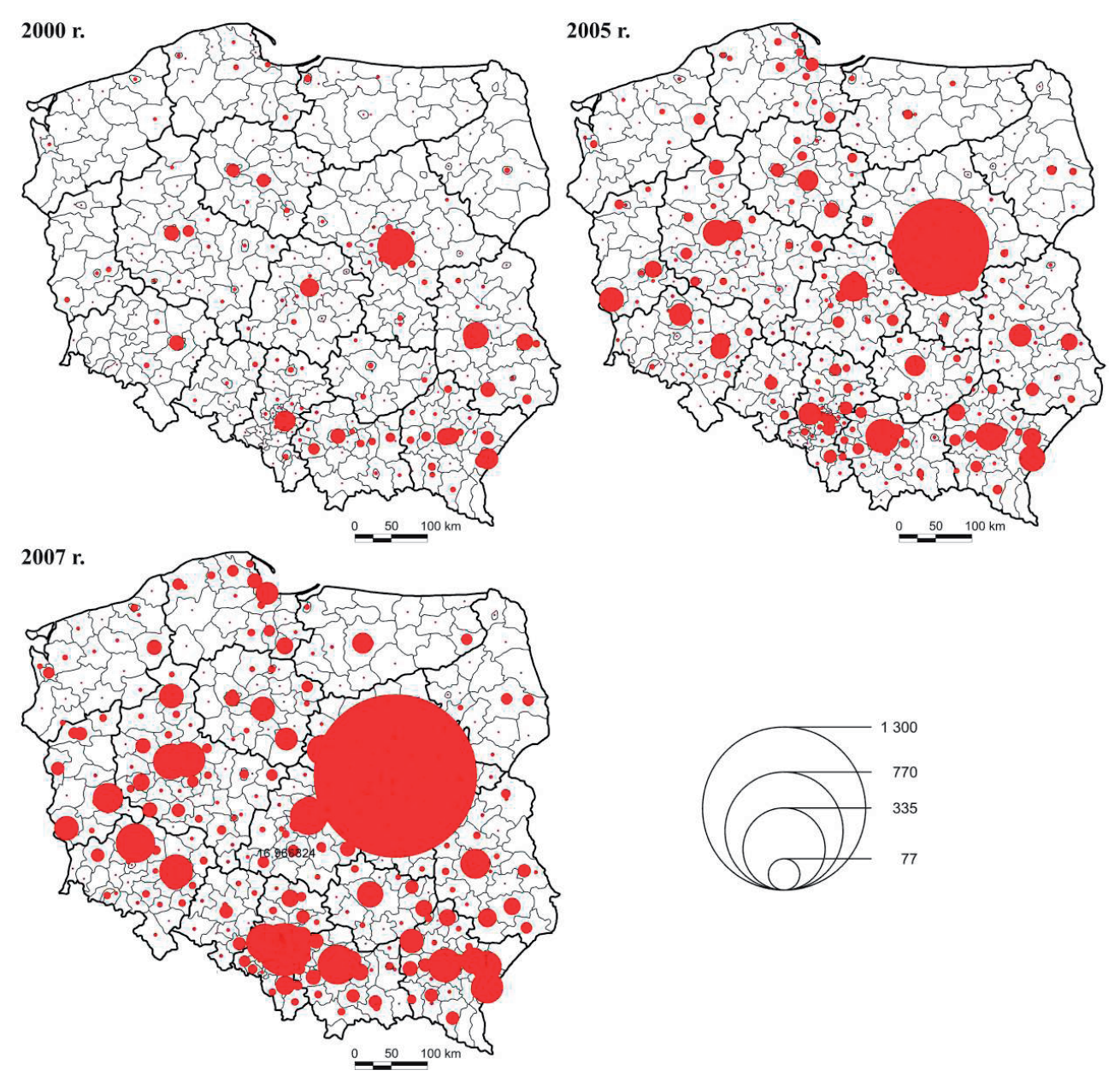

Ryc. 1. Eksport na Ukrainę (w mln USD) - 2000, 2005 i 2007 rok

Źródło: Opracowanie własne na podstawie materiałów Ministerstwa Finansów (Komornicki 2009)

i Lublin (blisko 5\%). W ujęciu wojewódzkim zdecydowanie największym udziałem eksportu na Białoruś odznaczają się stale województwa: podlaskie (blisko 7,5\%) i lubelskie.

Jak powszechnie wiadomo, rola Rosji jako polskiego partnera handlowego opiera się przede wszystkim na powiązaniach paliwowo-energetycznych w imporcie. Jednocześnie eksport, zwłaszcza w niektórych branżach, był w badanym okresie uzależniony od czynników politycznych (embarga na niektóre grupy produktów spożywczych). Znalazło to wyraz w wahaniach zarówno poziomu wywozu ogółem, jak i w zmianach jego rozkładu terytorialnego. Województwami skupiającymi eksport do Rosji są mazowieckie, podlaskie. Od lat 90. XX wieku rolę taką odgrywało też województwo warmińsko-mazurskie, sąsiadujące z obwodem kaliningradzkim (ryc. 3). W latach 2000-2007 podlaskie zachowało wysoką dynamikę wzrostu eksportu na kierunku rosyjskim. Jednocześnie relatywna rola województwa warmińsko-mazurskiego malała. Najwyższe wskaźniki wzrostu notowano natomiast w województwach Polski Zachodniej i, co charakterystyczne, w województwie świętokrzy- 

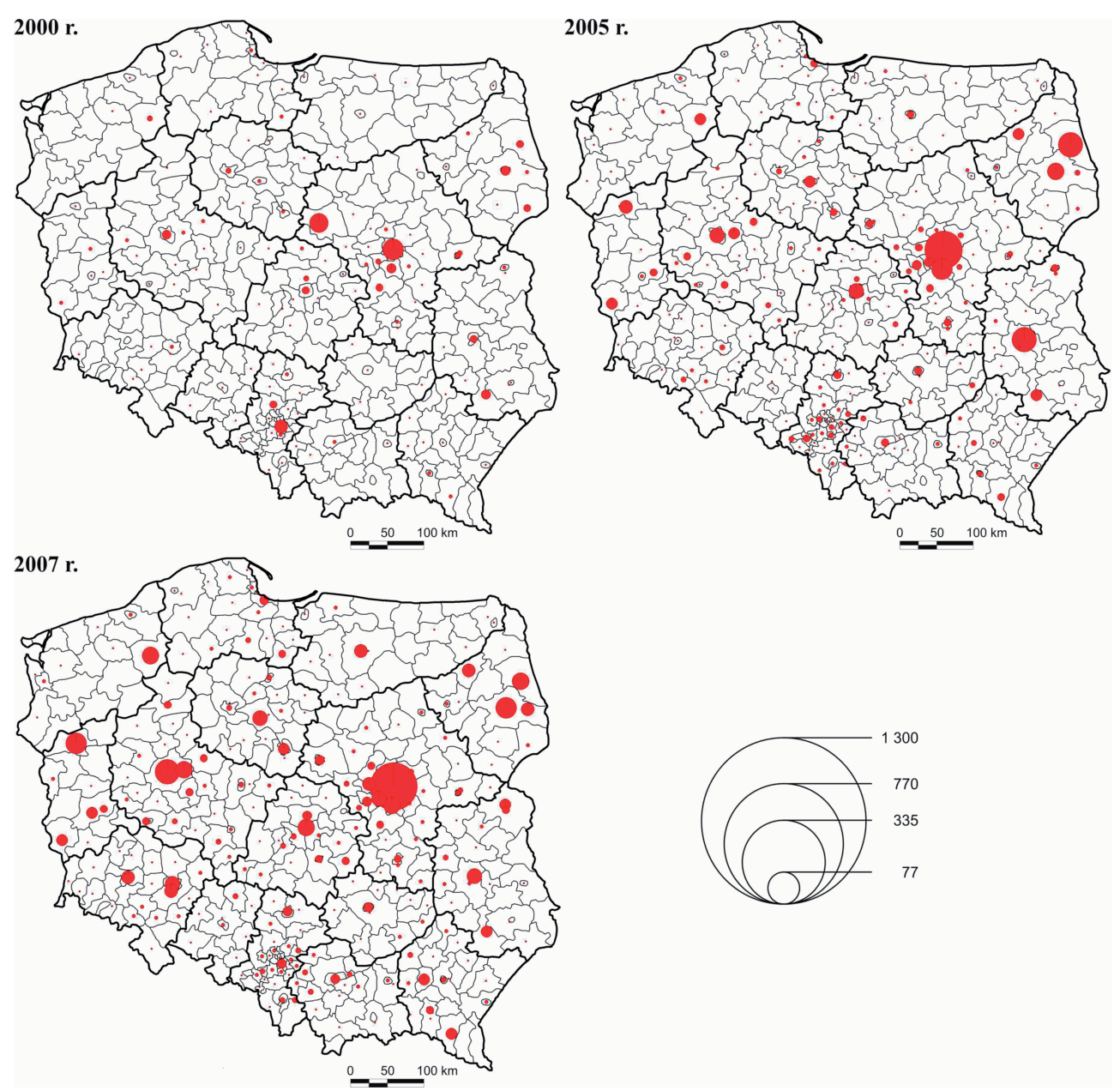

Ryc. 2. Eksport na Białoruś - 2000, 2005, 2007 rok

Źródło: Opracowanie własne na podstawie materiałów Ministerstwa Finansów (Komornicki 2010)

skim. W efekcie, podobnie jak w przypadku Ukrainy, doszło do wyrównywania się rozkładu przestrzennego jednostek o dużym znaczeniu partnera rosyjskiego. Można też przyjać, że uwarunkowanie politycznie, ograniczenia makroekonomiczne, najbardziej wpłynęły na lokalne powiązania w obszarze przygranicznym. Przykładem może być spektakularny spadek eksportu z powiatu ostródzkiego (zakłady mięsne w Morlinach).

Reasumując należy stwierdzić, że partnerzy w krajach sąsiednich są znaczącymi odbiorcami towarów wytworzonych na wschodnich obszarach przygranicznych Polski. Dostrzegając to znaczenie trzeba jednak pamiętać o trzech istotnych uwarunkowaniach natury ogólnej. Po pierwsze, województwa wschodnie (zwłaszcza lubelskie i podlaskie) generalnie w ograniczonym stopniu uczestniczą w polskiej wymianie handlowej. Tym samym nawet wysokie wartości procentowe nie przekładają się na znaczącą wartość wywożonych towarów. Po drugie, koncentracja eksportu na Ukrainę i do Rosji na obszarach przygranicznych systematycznie maleje, co traktować należy jako sytuację naturalną (jej dotychczasowy poziom wynikał 

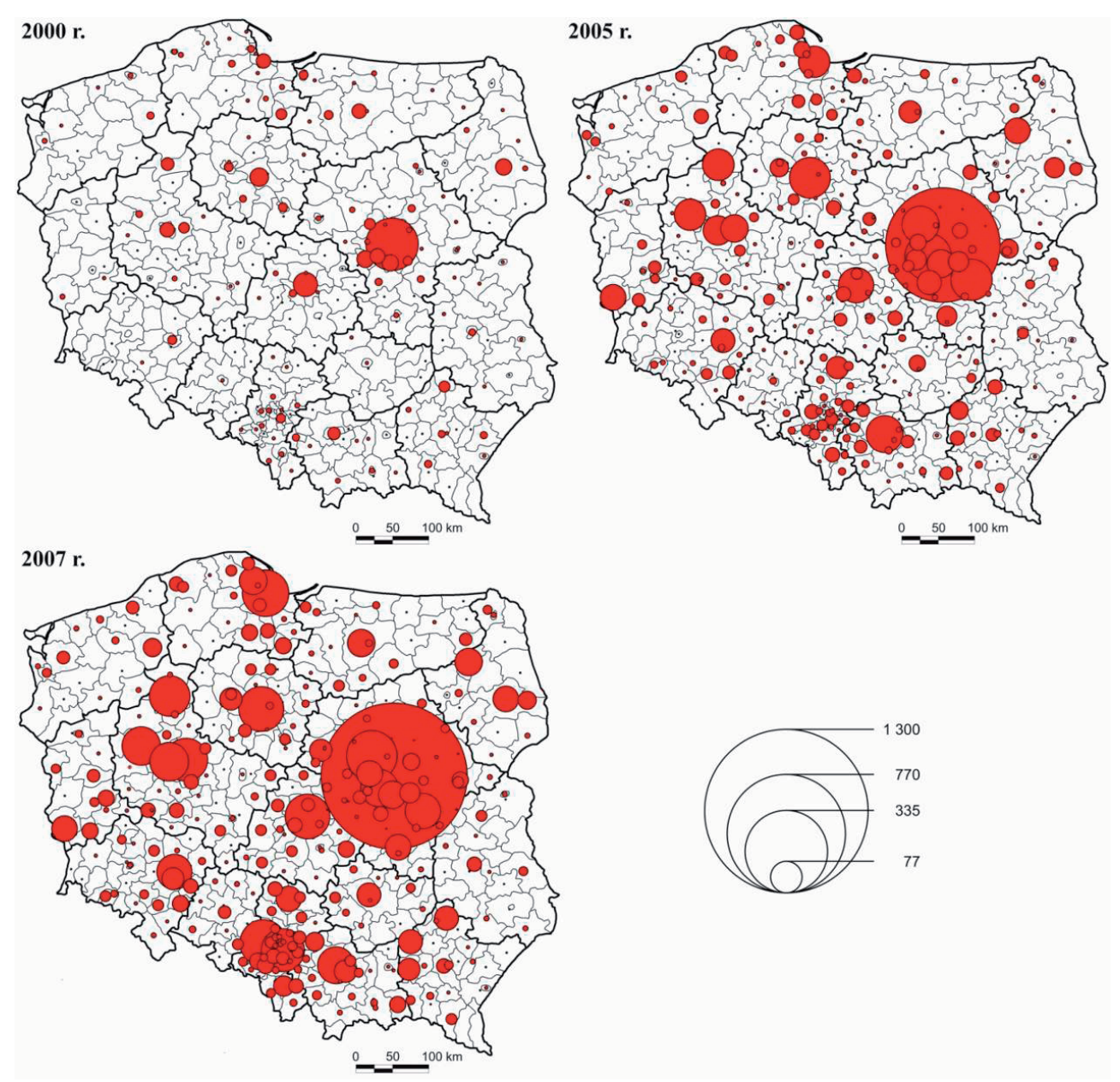

Ryc. 3. Eksport do Rosji (w mln USD) - 2000, 2005, 2007 rok

Źródło: Opracowanie własne na podstawie materiałów Ministerstwa Finansów (Komornicki 2009)

głównie z ogólnego braku rozwiniętych relacji gospodarczych, generowanych w głównych ośrodkach życia gospodarczego Polski).

Trzecim ważnym zagadnieniem są zagrożenia dla gospodarek lokalnych powodowane nadmierną koncentracją na rynkach wschodnich. Zgodnie w wynikami analizy regionalnego zróżnicowania zagrożeń związanych z kryzysem ekonomicznym lat 2008-2009 prognozowany ubytek eksportu (obliczony proporcjonalnie do spadku PKB w krajach docelowych) odniesiono do poziomu produkcji sprzedanej w powiatach. W efekcie najmniej odporne na zawirowania ekonomiczne okazały się zarówno niektóre regiony Polski Wschodniej, jak i zwarte przestrzennie grupy powiatów położonych na zachodzie kraju. W pierwszym przypadku było to wynikiem koncentracji na ryzykownych rynkach zbytu, zaś w drugim efektem ogólnego uzależnienia gospodarki od eksportu. Charakterystyczna okazała się niekorzystna sytuacja jednostek przygranicznych położonych w sąsiedztwie gra- 
nicy tak wschodniej, jak i zachodniej. Wśród powiatów o najwyższym poziomie wskaźnika ubytku eksportu względem produkcji znalazły się miasto i powiat Przemyśl, a także powiaty słubicki i suwalski. Jednocześnie jednak województwa wschodnie korzystnie wyróżniają się na tle kraju pod względem poziomu dywersyfikacji partnerów eksportowych.

\section{OBSŁUGA TRANZYTU}

W wielu dotychczasowych opracowaniach naukowych, a także w dokumentach strategicznych (w tym w obowiązującej Koncepcji Polityki Przestrzennego Zagospodarowania Kraju) przeceniana była rola tranzytu jako stymulatora rozwoju gospodarki ogółem oraz gospodarek lokalnych. Polska, a także jej wschodnie pogranicze dyskontować miały, zgodnie z tymi poglądami, zwornikowe położenie kraju przy szlakach transportowych łączących Rosję i Europę Zachodnią. Ostatnio założenia takie bywają coraz częściej kwestionowane (Komornicki 2007). Dotyczy to zwłaszcza ciężkiego transportu samochodowego, generującego ogromne koszty zewnętrzne (zwłaszcza środowiskowe oraz związane z bezpieczeństwem ruchu drogowego). Bilans strat i korzyści jest najbardziej problematyczny w przypadku przewozów między państwami trzecimi. Dlatego istotne jest wydzielenie tych szlaków transportowych, po których odbywa się polska wymiana handlowa służąca podmiotom gospodarczym funkcjonującym na terenie kraju. Służyć temu mogą dane na temat ruchu granicznego samochodów ciężarowych oraz informacje obrazujące rozkład eksportu i importu na korytarze transportowe.

Ruch pojazdów ciężarowych przez polską granicę wschodnią pozostawał w całym okresie 1990-2007 mniej uzależniony od czynników politycznych i mikroekonomicznych niż ruch osobowy. Wykazywał on dość konsekwentną tendencję wzrostową (poza odcinkiem białoruskim; ryc. 4). W roku 1990 największa część ruchu granicznego pojazdów ciężkich w kierunku wschodnim skoncentrowana była na granicy białoruskiej, a konkretnie na przejściu granicznym w Terespolu. Lata 1991-1998 charakteryzowały się szybkim przyrostem ruchu na wszystkich odcinkach. Rok 1998 przyniósł gwałtowne załamanie ruchu z Białorusią i jednoroczne zatrzymanie wzrostu na granicach z Litwą oraz Ukrainą. Ruch towarowy z Rosją pozostawał relatywnie niewielki. Po roku 2000 obserwujemy ponowny wzrost na wszystkich odcinkach. Na granicy z Białorusią trwał on tylko do roku 2003, po czym nastąpiła stagnacja i niewielki wzrost w latach 2006-2007 (dopiero wówczas udało się osiagnąć poziom ruchu z roku 1997).

Członkostwo Polski i Litwy (a także Łotwy i Estonii) w Unii Europejskiej spowodowało spektakularny wzrost ruchu polsko-litewskiego w latach 2004-2006. Budzisko stało się obok Świecka na granicy niemieckiej najbardziej obciążonym ruchem towarowym polskim przejściem granicznym. Relatywnie szybki wzrost ruchu ma też miejsce na granicy z Ukrainą, po roku 2005 niewielki spadek wystąpił natomiast w ruchu polsko-rosyjskim. Rok 2008 i członkostwo Polski w strefie Schengen nie wpłynęły zasadniczo na wzrostową tendencję ruchu na granicy białoruskiej i ukraińskiej oraz na trend spadkowy w przypadku granicy rosyjskiej.

Struktura granicznego ruchu towarowego wg kraju rejestracji pojazdu musi być interpretowana z dużą ostrożnością. Miejsce rejestracji pojazdu nie determinuje bowiem przynależności państwowej firmy przewozowej. Jeszcze inne może być obywatelstwo kierującego samochodem. Na początku lat 90 . uczestnikami ruchu na wszystkich odcinkach były 


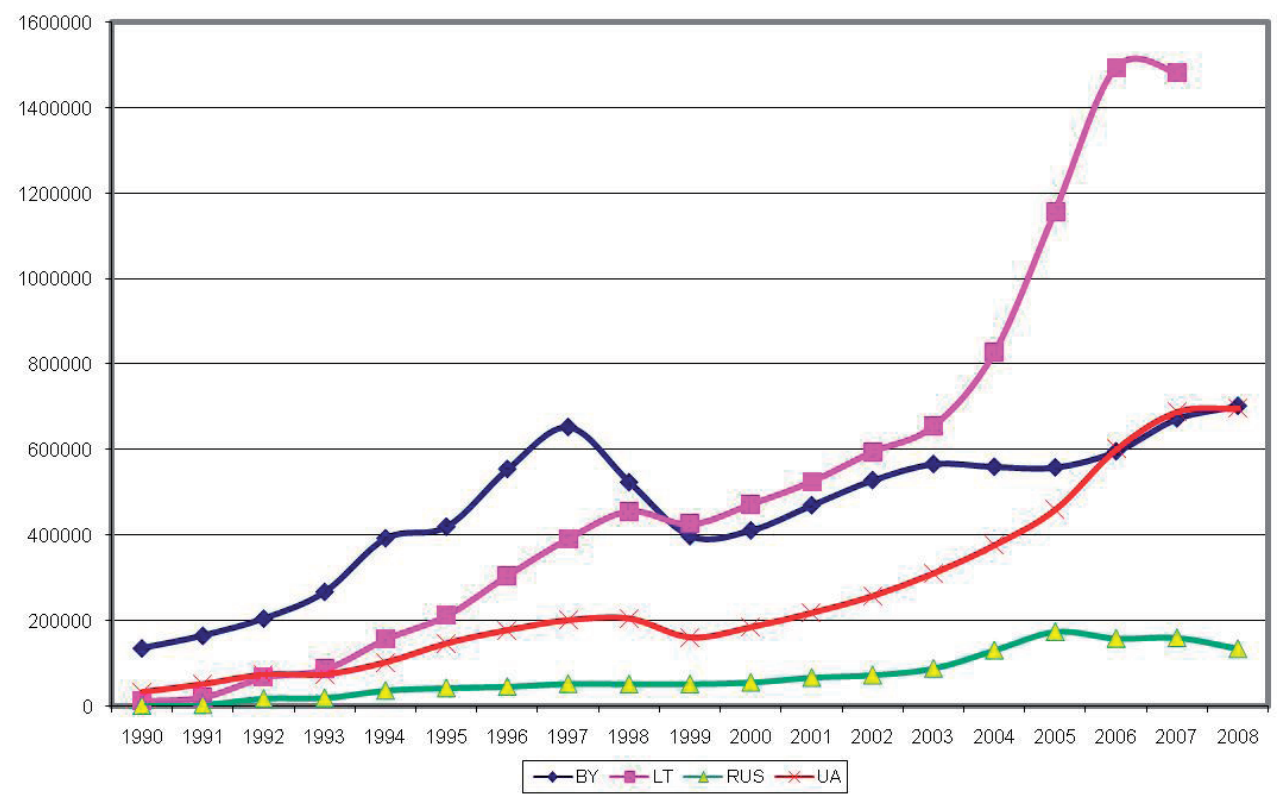

Ryc. 4. Ruch pojazdów ciężarowych przez granicę wschodnią w latach 1990-2008

Źródło: Opracowanie własne na podstawie danych Straży Granicznej

w równym stopniu pojazdy polskie i obce. Wyjątkiem była granica białoruska, przez którą wiódł tradycyjny szlak przejazdu samochodów ciężarowych ze Związku Sowieckiego do NRD i Europy Zachodniej. Począwszy od lat 1992-1994 sytuacja zaczęła się zmieniać i na wszystkich kierunkach zaczęły dominować samochody ciężarowe z rejestracją zagraniczną. $\mathrm{Z}$ upływem kolejnych lat ich przewaga w strukturze systematycznie rosła. Była to sytuacja symetryczna do występującej na granicy polsko-niemieckiej, gdzie dominowały samochody polskie. Szczególnie niski udział pojazdów krajowych utrzymywał się na granicy litewskiej, relatywnie wysoki zaś na granicy rosyjskiej (Komornicki 2010).

Obraz przestrzenny rozkładu polskiego handlu zagranicznego na korytarze transportowe (ryc. 5) odbiega wyraźnie od rozkładu ruchu pojazdów ciężarowych przez granicę wschodnią. Jak już wspomniano, pozwala to na dość precyzyjne wskazanie kierunków międzynarodowych, które służą głównie tranzytowi oraz które obsługują eksport polskich podmiotów gospodarczych działających na terytorium Polski. Do pierwszej kategorii należy bez wątpienia zaliczyć szlak Via Baltica, a do pewnego stopnia także korytarze polsko-rosyjskie oraz szlak Lublin-Lwów. Z kolei kluczowymi dla polskiego wywozu pozostają kierunki Warszawa-Mińsk, Warszawa-Kijów oraz Kraków-Kijów.

Istotnym przyczynkiem do określenia faktycznych korzyści odnoszonych przez obszary przygraniczne $\mathrm{z}$ odbywającego się po ich terenie ruchu tranzytowego mogą być także informacje dotyczące rozkładu noclegów udzielonych cudzoziemcom na terenie Polski. W Polsce Wschodniej miejscami koncentracji nocujących Ukraińców i Białorusinów pozostają głównie największe miasta regionu (zwłaszcza Białystok). Koncentracja taka nie występuje wzdłuż szlaków drogowych. Jednocześnie zauważalne liczby noclegów udzielonych obywatelom tych państw (a także Rosjanom) występują na kierunkach głównych dróg 


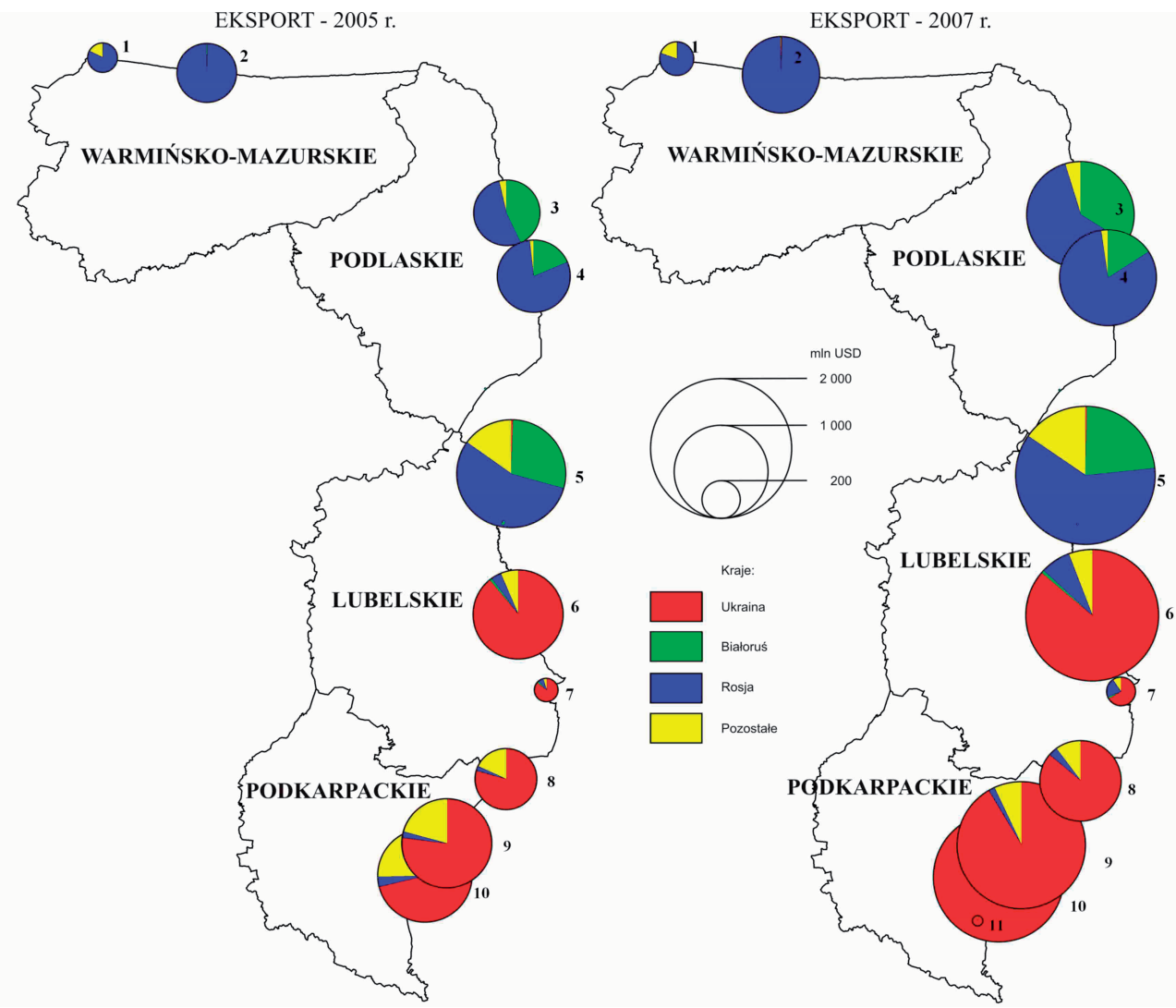

Ryc. 5. Eksport wg przejść granicznych 2005-2007

Źródło: Opracowanie Barbara Szejgiec na podstawie danych Ministerstwa Finansów

w sąsiedztwie granicy polsko-niemieckiej (Komornicki 2010). Wskazuje to na fakt, że postoje w ruchu tranzytowym (nie tylko towarowym) mają miejsce raczej przed przekroczeniem granicy wyznaczającej poziom cen usług hotelowych i gastronomicznych. Dlatego beneficjentami tranzytu są pogranicza o cenach niższych (czyli ukraińskie w odniesieniu do granicy ukraińsko-polskiej i polskie w odniesieniu do granicy polsko-niemieckiej).

\section{HANDEL NIEREJESTROWANY}

Specyficznymi formami kontaktów ekonomicznych w skali lokalnej są handel i usługi przygraniczne. Zjawisko to rozpatrywane jest zarówno na gruncie badań turystyki, jak i w trakcie analiz ekonomicznych. Przez prawie cała dekadę lat 90. obroty bazarowe na obszarach przygranicznych równoważyły polski deficyt w handlu oficjalnym. W roku 1994 klienci bazarów i sklepów z krajów sąsiednich zostawili w Polsce 6 mld USD. Sprzyjały temu ogromne różnice w poziomie dochodów ludności oraz cen występujące zarówno pomiędzy Polską a Niemcami, jak i między Polską i obszarem byłego ZSRR (Powęska 2002). 
Obecnie jego znaczenie zmalało, m.in. na skutek wyrównywania się cen oraz zmian w polityce celnej niektórych krajów sąsiednich. Handel na granicy zachodniej i południowej miał $\mathrm{z}$ reguły charakter detaliczny, tym samym nie tworzył on ścisłych powiązań ekonomicznych, miał natomiast istotny wpływ na interakcje społeczne (masowy ruch graniczny), w tym indywidualne. Dla osób uczestniczących w handlu przygranicznym na granicy wschodniej był on natomiast z reguły półoficjalną działalnością gospodarczą. Mimo dużego natężenia ruchu brało w nim udział relatywnie mało osób, które jednak wielokrotnie przekraczały granice państwową. Ponadto, o ile osoby przyjeżdżające do Polski w celach handlowych z Niemiec, Czech i Słowacji z reguły udawały się do miejscowości położonych przy samej granicy, o tyle przybysze z Białorusi, Ukrainy i Rosji często podróżowali w głąb kraju (najczęściej do miast położonych na kierunku głównych szlaków drogowych i linii kolejowych). Znalazło to odzwierciedlenie w rozmieszczeniu bazarów i targowisk przygranicznych (Węcławowicz i in. 2006), będących specyficznym miejscem koncentracji interakcji międzynarodowych.

Do bezpośrednich czynników, które wpłynęły na ogromną dynamikę wzrostu ruchu granicznego między Polską a krajami Europy Wschodniej po roku 1990, zaliczyć należy m.in. (Komornicki 1999):

- ubożenie społeczeństw byłego Związku Radzieckiego (motywacja do przyjazdów do Polski w celu odsprzedaży towarów niskiej jakości; lata 1993-1994) oraz części społeczeństwa polskiego (popyt na ww. towary);

- konkurencyjność towarów wytwarzanych przez niektóre gałęzie polskiego przemysłu na rynkach wschodnich sąsiadów, połączona z ogromnym wzrostem cen artykułów konsumpcyjnych w tych krajach (motywacja ekonomiczna do drobnego importu z Polski);

- wysokie cło i akcyza na wyroby alkoholowe, tytoniowe i paliwa w Polsce, skłaniające do drobnego przemytu zza granicy wschodniej.

Wiele z wymienionych czynników miało charakter krótkoterminowy i zarazem niestabilny. Efektem były fluktuacje natężenia ruchu granicznego. Każdorazowo zmiany miały ostrzejszy charakter na granicy białoruskiej niż ukraińskiej. Ruch przez granicę polsko-litewską uległ stabilizacji i nie wykazywał znaczniejszych zmian w całym okresie 1993-2003. Wprowadzenie przez Polskę wiz dla obywateli krajów sąsiednich (poza Litwą) w październiku 2003 r. spowodowało gwałtowny spadek ruchu, widoczny wyraźnie w zestawieniach miesięcznych. W przypadku granic z Ukraina, a także z obwodem kaliningradzkim Federacji Rosyjskiej dość szybko doszło jednak do ponownego wzrostu liczby przekroczeń granicy. $\mathrm{Na}$ granicy białoruskiej analogiczny proces trwał znacznie dłużej. Załamanie ruchu w roku 2008 (po wejściu do strefy Schengen) skutkowało bardzo różnymi tendencjami w zakresie jego struktury. Na granicy rosyjskiej spadek objął tak Polaków, jak i cudzoziemców, na ukraińskiej spadkowi ruchu obywateli ukraińskich towarzyszył dalszy wzrost liczby przekraczających granicę Polaków. W przypadku granicy białoruskiej, szybkiemu spadkowi liczby cudzoziemców odpowiadał powolny spadek liczby Polaków.

Przypadek granicy polsko-ukraińskiej dowodzi, że w warunkach dużych różnic w cenach towarów (zwłaszcza objętych akcyzą) drobny handel realizowany będzie przez mieszkańców tej strony granicy, którzy ponoszą mniejsze koszty transakcyjne. Wprowadzenie drogich wiz dla obywateli Ukrainy nie ograniczyło ich przyjazdów w celu poszukiwania pracy. Miało jednak wpływ na ich udział w wahadłowym ruchu handlowym. Został on przejęty przez zamieszkujących obszary przygraniczne obywateli polskich, którzy nadal podróżować mogą na Ukrainę w ruchu bezwizowym. 
Wraz z przejęciem handlu przez Polaków oraz jednoczesnym znaczącym ograniczeniem go do alkoholu, papierosów i paliw wrosła rola zagrożeń związanych z tym zjawiskiem, a zmalały generowane przez nie korzyści. Wyniki badań terenowych dotyczących struktury ruchu granicznego realizowanych latem 2008 roku (Komornicki 2010) potwierdzaja te wnioski. Jednocześnie wskazują one na wyraźny wzrost (względem lat poprzednich) lokalności ruchu przygranicznego. Jest to zjawisko analogiczne do obserwowanego w latach 90. na granicy polsko-niemieckiej, kiedy to na polskie bazary klienci niemieccy przyjeżdżali sukcesywnie z coraz mniejszej odległości (Komornicki, Powęska 1996). Te same badania pośrednio wykazały, że dla części Polaków wyjazdy zarobkowe na Ukrainę są obecnie dodatkowym, a nie podstawowym źródłem utrzymania. Wyniki takie należy oceniać pozytywnie. Analogicznych zmian nie obserwuje się niestety w relacjach z Rosją i Białorusią.

\section{Podsumowanie}

W okresie transformacji przedakcesyjnej polskie wschodnie obszary przygraniczne wygenerowały specyficzne endogeniczne procesy rozwojowe. Były one oparte nie tylko na handlu bazarowym. Zakupy dokonywane przez klientów z Białorusi, Rosji i Ukrainy były w znacznej części hurtowe. Większość z nich nie trafiała do handlowych statystyk, ale z czasem na obszarach przygranicznych (zwłaszcza w rejonie dużych przejść granicznych) wygenerowały one produkcję na rynek wschodni, a później także rejestrowany eksport. Tym samym z punktu widzenia oficjalnej wymiany handlowej to właśnie wschodnie obszary przygraniczne stały się beneficjentami swojego położenia. Akcesja Polski do Unii Europejskiej miała wpływ przede wszystkim na drobny handel walizkowy, gdzie istotnym elementem rachunku ekonomicznego stały się koszty wiz na obszar Schengen. Jak pokazują analizowane materiały pośrednio zahamowała ona także rozwój wymiany oficjalnej na obszarach przygranicznych, zwłaszcza tej, której podmiotami były małe i średnie przedsiębiorstwa.

Przeprowadzona analiza wskazuje dość jednoznacznie, że po roku 2003/2004 na wschodzie Polski zmalało znaczenie położenia przygranicznego jako stymulatora intensywności interakcji z krajem sąsiednim. Rola wymiany towarowej z Białorusią, Rosją i Ukrainą w gospodarce obszarów przygranicznych maleje i staje się coraz bardziej selektywna przestrzennie. Liczba subregionów korzystających na wymianie także maleje, a ich lokalizacja zmienia się względem rozkładu ukształtowanego w latach 90. Wymiana towarowa koncentruje się stopniowo w większych ośrodkach i w niektórych tylko jednostkach lokalnych. Korzyści związane z obsługą ruchu transgranicznego przenoszą się z przejść białoruskich na kierunek litewski i ukraiński. Korzyści związane $\mathrm{z}$ handlem indywidualnym koncentrują się w gminach przygranicznych w bezpośrednim sąsiedztwie przejść granicznych.

Wzrasta rola zagrożeń związanych z wymianą towarową. Nadmierne skoncentrowanie eksporterów na rynku krajów sąsiednich zwiększa ryzyko „,importu” sytuacji kryzysowych. Koncentracja na rynkach o niższych wymaganiach jakościowych może ponadto prowadzić do konserwowania przestarzałych technologii i opóźniania zmian strukturalnych oraz organizacyjnych. Ciężki tranzyt towarowy generuje znaczne koszty zewnętrzne, a handel przygraniczny stanowi w coraz większym stopniu nieuczciwą konkurencję dla lokalnych przedsiębiorców. Przemyt poprzez kryminalizację podejmowanych aktywności sprzyja potencjalnie wykluczeniu niektórych przygranicznych grup społecznych. 
Dlatego też, w perspektywie długoterminowej, zmniejszenie roli położenia przygranicznego w generowaniu powiązań handlowych odbierać można pozytywnie, jako równomierne włączenie całej polskiej przestrzeni ekonomicznej w system europejski i globalny. W krótszym horyzoncie czasowym zjawisko niesie jednak pewne zagrożenia, przeciwdziałanie którym powinno być przedmiotem zainteresowania polityki regionalnej.

Zmiany w kierunkach wymiany towarowej dowodzą, że Polska Wschodnia coraz bardziej poszukuje powiązań z Europą Zachodnią. Przedsiębiorstwa z kilku konkretnych podregionów wymagają wsparcia eksportu na rynki zróżnicowane geograficznie, tak aby firmy te nie były uzależnione od sytuacji ekonomicznej w krajach sąsiednich. Z drugiej strony istnieją możliwości lepszego dyskontowania renty przygranicznej zwłaszcza na obszarach sąsiadujących z obwodem kaliningradzkim Federacji Rosyjskiej. Dyskontowaniu ruchu tranzytowego może służyć wprowadzenie rozwiązań intermodalnych z terminalami w strefie przygranicznej (potencjalnie koncentrującymi szerszą działalność usługową). Priorytetem powinny być inwestycje transportowe na szlakach obsługujących polski eksport. Należy dążyć do udrożnienia formalnego istniejących obiektów w ramach obowiązujących zasad (np. MRG, wspólne odprawy, oddzielenie ruchu turystycznego od drobnego handlu). Pozwoli to na wzrost ruchu ściśle turystycznego, który przyniesie obszarom przygranicznym innego rodzaju korzyści gospodarcze.

\section{Literatura}

Gorzelak G. (red.), 2009, Geografia polskiego kryzysu - kryzys peryferii, czy peryferia kryzysu, Euroreg, Warszawa

Komornicki T., 1999, Granice Polski. Analiza zmian przenikalności w latach 1990-1996, Geopolitical Studies, vol. 5, IGiPZ PAN, Warszawa, s. 348

Komornicki T., 2009, „Ocena charakteru, struktury i intensywności polskiego eksportu w kontekście celów polityki regionalnej, na poziomie województw”, ekspertyza dla Ministerstwa Rozwoju Regionalnego, maszynopis, Warszawa

Komornicki T., Powęska H., 1996, Przejścia graniczne: Kostrzyn, Stubice, Świecko, Gubin podstawowe funkcje i strefa oddziaływania na terenie Polski i Niemiec, Zeszyty IGiPZ PAN, nr 37, s. 5-40, 12 tabel, 4 mapy, Warszawa

Komornicki T., 2007, Rola infrastruktury transportowej w rozwoju kraju - wyzwania wobec kohezji przestrzennej, [w:] T. Markowski, A. Stasiak (red.), Rola polskiej przestrzeni w integrujacej się Europie, Biuletyn KPZK PAN, z. 233, Warszawa, s. 63-86

Komornicki T., [w druku], Assesment of region al economic hazard based on export statistics, Geopolitiocal Studies, vol. 13, Uniwersytet Rzeszowski, IGiPZ PAN

Komornicki T., 2010, Przepływy osób i towarów przez polski odcinek zewnętrznej granicy Unii Europejskiej, raport końcowy z projektu badawczego MNiSW

Węcławowicz G., Bański J., Degórski M., Komornicki T., Korcelli P., Śleszyński P., 2006, Przestrzenne zagospodarowanie Polski na poczatku XXI wieku, IGiPZ PAN, Warszawa

\section{Role of trade with the Eastern neighbours of Poland in the local economy}

The purpose of this article is to investigate the current role of trade with Russia, Ukraine and Belarus in the local economy of East Poland. It is assumed that the importance of trade with neighbouring countries can be expressed through: (a) export of goods that are made in a given spatial 
unit to the markets of adjacent countries; (b) providing service for the needs of transit traffic, including in particular the freight traffic generated by Polish foreign trade; (c) small-scale, unregistered trade along the border areas. The research study focuses mainly on the four borderland voivodships. The analysis shows that after the years 2003/2004 in East Poland there has been a declining importance of the borderland location as a stimulus factor which contributes to intensive interactions with the neighbouring countries. The role of trade of goods with Belarus, Russia and Ukraine in the economy of borderland regions is becoming ever less important and ever more spatially selective. The advantages derived from trans-border traffic services are increasingly evident in the border crossings leading into Lithuania and Ukraine, with a rather declining significance of those crossings with Belarus. The advantages linked to peddling small items are mainly concentrated in the border gminas (communes) that are located in the close neighbourhood of the border crossings.

At the same time, however, risks related to trade of goods are playing ever more important role, since excessive concentration of exporters to the markets of the neighbouring countries may pose a threat of "importing" the crisis. Intensive transit of goods generates considerable external costs, while trans-border illegal trading is increasingly becoming an unfair trade for local entrepreneurs.

Doc. dr hab. Tomasz Komornicki

Instytut Geografii i Przestrzennego Zagospodarowania PAN

Warszawa

e-mail: t.komorn@twarda.pan.pl 